\title{
ЗАХИСТ ПРАВ ФІЗИЧНИХ ОСІБ - ПОЗИЧАЛЬНИКІВ ТА ЇХ ВІДПОВІДАЛЬНІСТЬ ЗА НЕВИКОНАННЯ УМОВ КРЕДИТНОГО ДОГОВОРУ
}

\author{
СЕРДЮК Олександр Олександрович - здобувач кафедри цивільного права \\ № 2 Національного юридичного університету імені Ярослава Мудрого \\ DOI:10.32782/LAW.2020.1.26 \\ УДК: 347.451 .8 (477)
}

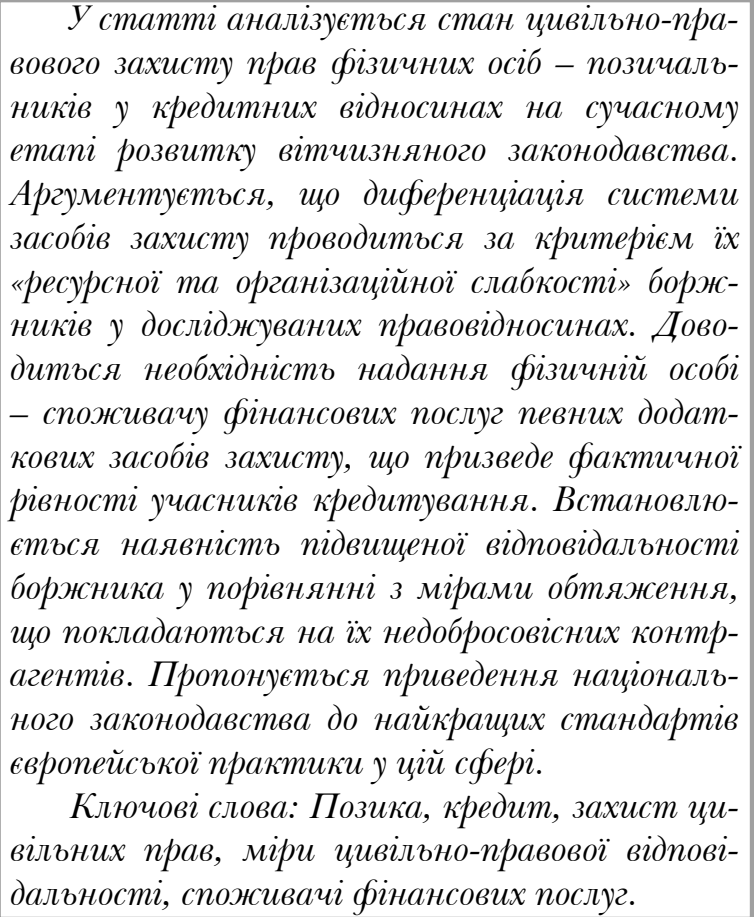

Постановка проблеми

У сучасних умовах розвитку країни вітчизняна економіка потребує принципових змін у формуванні а також правовому регулюванні кредитних відносин. Кризові явища, що відбуваються протягом останніх років на фінансовому ринку України, передумовами яких стали політична ситуація та дестабілізація економічної активності суб'єктів господарського обороту, негативно вплинули на діяльність кредитних інститутів. Найважливішим питанням, що ставиться перед законодавством і стосується усіх ви- дів кредитування $є$ ефективний захист прав і охоронюваних законом інтересів учасників кредитних правовідносин, як один 3 найважливіших факторів підтримання стабільності економіки країни в цілому.

Наразі в Україні на низькому рівні ефективності та дієвості знаходяться механізми захисту прав споживачів фінансових послуг, водночас невирішеними лишаються питання стосовно меж їхньої відповідальності за невиконання умов кредитного договору. Варто зауважити, що на сьогодні, внаслідок зменшення доходів учасників цивільного обороту, значно зросла кількість судових справ, пов'язаних з порушеннями прав кредиторів. Складність полягає і в тому, що позичальники фактично виступають слабшою стороною у досліджуваних договірних відносинах оскільки внаслідок необізнаності у багатьох фахових питаннях кредитування, вони зазвичай приєднуються до запропонованих фінансовими установами умов кредитного договору, що у свою чергу може призвести до зловживань з боку недобросовісних контрагентів. Звідси випливає необхідність пошуку балансу співвідношення справедливих мір цивільно-правової відповідальності споживачів фінансових послуг та способів захисту їхніх прав, як слабшої сторони у таких правовідносинах.

\section{Аналіз літератури}

Питаннями захисту цивільних прав та законних інтересів учасників цивільних відносин займалося багато видатних вітчиз- 
няних науковців, таких, як: Н. П. Бондар, I. В. Венідиктова, I. О. Дзера, О. О. Кот, О. Д. Кузнєцова, В. В. Ауць, Я. М. Шевченко, В. А. Яроцький та ін., утім, питання специфіки та особливостей захисту прав в сфері кредитних відносин лишилося поза увагою цивілістичної доктрини.

Метою статті є дослідження стану цивільно-правового захисту прав фізичних осіб - споживачів фінансових послуг в Україні, а також меж їх цивільно-правової відповідальності.

\section{Виклад матеріалу}

Відповідно до ч. 1 ст. 509 ЦК України, зобов'язання - це правовідношення, за яким одна сторона (боржник) зобов'язується вчинити на користь іншої сторони (кредитора) певну дію (передати майно, виконати роботу, надати послугу, сплатити гроші тощо) або утриматися від іiі вчинення, а кредитор має право на вимагати таке виконання [1]. Із визначення можна зробити висновок про законодавче встановлення певної пріоритетності становища кредитора перед боржником, оскільки останній зобов'язується переважно виконувати обов'язки перед кредитором. Таким чином, різний статус учасників кредитних відносин має оцінюватись не лише $з$ урахуванням їх соціального стану (де, очевидно боржники і кредитори можуть мати різну ступінь доступу до ресурсів та інструментів захисту) але й особливостей класичних цивілістичних підходів у сфері зобов'язального права. Захист інтересів кредитора і фактично і концептуально превалює над інтересом зобов'язаної особи. Такий дисбаланс інтересів і відповідно правових ресурсів їх захисту потребує належної оцінки.

Незважаючи на суспільний запит створення відповідного інструментарію, сучасна цивілістична модель захисту прав боржника, як «слабкого учасника» кредитних відносин знаходиться тільки у стадії формування. Наразі необхідним є належне правове забезпечення та відмежування інтересів фізичної особи - боржника, що не пов'язані зі здійсненням професійної чи підприємницької діяльності й спрямовані на задоволення осо- бистих, сімейних та інших соціальних потреб, як умови саморозвитку особистості. У таких відносинах досить складно знайти загальну формулу балансу інтересів боржника та кредитора, відповідно - балансу доступних засобів захисту. Водночас безперечною є важливість існування спеціальних нормативних (законодавство) і позанормативних (договірні умови) інструментів, в яких би презюмувалась фактична рівність засобів правового захисту учасників із різним статусом. Останне свідчить про необхідність створення в Україні деталізованого, спеціального законодавства у сфері споживчого кредитування (Законів «Про споживче кредитування» та «Про захист прав споживачів фінансових послуг»), що передбачає встановлення нормативних засад для підвищення можливостей використання боржниками різних засобів правового захисту.

Диференціація системи засобів захисту прав та інтересів учасників кредитних відносин за критерієм їх "ресурсної та організаційної слабкості» є одним із ключових принципів спеціального законодавства про статус споживачів фінансових послуг. Загалом все законодавство про захист прав споживачів базується на «презумпції слабкості споживача» i необхідності запровадження спеціальних додаткових засобів захисту. Однак, у сфері кредитних відносин (як і в деяких інших сферах) реалізація цього підходу потребує відходу від ключового принципу цивільного законодавства - рівності прав учасників цивільних відносин. Хоча така «позитивна нерівність»у підсумку має компенсаційний характер, надає слабкій стороні певні додаткові засоби (права) або покладає на кредитора додаткові зобов'язання і приводить до фактичної рівності учасників. Утім, аналіз положень сучасного вітчизняного законодавства свідчить про наявність підвищеної відповідальності боржника у порівнянні $з$ мірами обтяження, що покладаються на їх недобросовісних контрагентів. Так, на сьогодні у вітчизняних нормативно-правових актах належним чином не врегульовані підстави та порядок застосування санкцій до кредитних установ за порушення прав споживачів фінансових послуг. Фактично, останні можуть користуватися загальними 


\section{Цивільне, підприсмницьке, господарське та трудове право}

способами захисту, передбаченими цивільним законодавством (сплата неустойки, відшкодування збитків). Якщо фінансова установа не погоджується добровільно сплатити суму неустойки та відшкодувати збитки, споживачеві доведеться звертатися до суду. Утім, спеціальних засобів захисту вітчизняне законодавство не передбачає: не встановлено ні адміністративної відповідальності, ні фінансових санкцій за порушення прав споживачів у сфері кредитування.

Що стосується відповідальності фізичних осіб - позичальників, це питання потребує більш детального вивчення.

Обов'язковою складовою правової характеристики будь-якого цивільно-правового договору виступає аналіз відповідальності за його невиконання. Як зазначав О. С. Йоффе, цивільно-правова відповідальність є санкцією за правопорушення, що тягне за собою настання для порушника негативних наслідків у вигляді позбавлення суб'єктивних прав або покладання нових чи додаткових цивільно-правових обов'язків [2, с. 25].

На сьогодні, спеціальною правовою нормою, що встановлюе відповідальність споживача за кредитним договором є ст. 21 Закону України «Про споживче кредитування» [3], яка загалом є бланкетною i відсилає до загальних положень Цивільного Кодексу. Отже наслідком невиконання умов кредитного договору є відшкодування збитків та сплата неустойки. Водночас, положення Кримінального кодексу України дозволяють зробити висновок про можливість накладання на споживачів фінансових послуг кримінально-правових санкцій. Підставами застосування мір кримінальної відповідальності у цьому випадку є надання позичальником завідомо неправдивої інформації банкам чи іншим кредиторам із метою одержання кредитів (ст. 222 КК України) та вчинення незаконних дій із заставленим майном (ст. 388 КК України) [4].

Цивільна відповідальність споживачів за невиконання умов кредитного договору полягає у відшкодуванні кредиторові збитків, сплаті неустойки чи втраті застави. Застосування одного із цих заходів відповідальнос- ті чи їх комбінації визначається договором 3 позичальником.

Виходячи 3 легального визначення кредитного договору, основним обов'язком позичальника є повернення отриманої грошової суми та сплата процентів за користування нею. Відповідно до ст. 1050 ЦК України, якщо позичальник своєчасно не повернув суму позики, він зобов' язаний сплатити грошову суму відповідно до статті 625 цього Кодексу. Частиною 2 вказаної правової норми встановлюється, що у разі прострочення повернення чергової частини суми позики (якщо такий обов'язок був встановлений договором) позикодавець має право вимагати дострокового повернення частини позики, що залишилася, та сплати процентів, належних йому відповідно до статті 1048 цього Кодексу.

Практика укладання кредитних договорів свідчить про встановлення кредитодавцями підвищених процентів за користування сумою кредиту у випадку порушення кінцевого строку його повернення. Поряд 3 умовою про збільшення відсотків за користування кредитом у таких договорах, як правило, міститься умова про стягнення неустойки за несвоєчасне повернення коштів або сплату процентів. У зв'язку з цим, часто виникає питання стосовно можливості одночасного застосування до споживача мір цивільно-правової відповідальності, встановленої договором та ст. 625 ЦК України, а саме, ототожнення правової природи трьох процентів річних як відповідальності за порушення грошового зобов'язання та неустойки, встановленої договором або законом.

Згідно 3 п. 3 ч. 1 ст. 611 ЦК України у разі порушення зобов'язання настають правові наслідки, встановлені договором або законом, зокрема сплата неустойки. Статтею 549 цього Кодексу встановлено, що неустойкою (штрафом, пенею) є грошова сума або інше майно, які боржник повинен передати кредиторові у разі порушення боржником зобов'язання. Формами неустойки є штраф і пеня. Штрафом $є$ неустойка, що обчислюється у відсотках від суми невиконаного або неналежно виконаного зобов'язання (ч. 2 ст. 549 ЦК України). Пенею є неустойка, що об- 
числюється у відсотках від суми несвоєчасно виконаного грошового зобов'язання за кожен день прострочення виконання (ч. 3 ст. 549 ЦК України). При цьому, що важливо, неустойка має подвійну природу та виконує функції як виду забезпечення зобов' язання, так і міри (форми) цивільно-правової відповідальності [2, с. 41].

Відповідно до ч. 2 ст. 625 ЦК України боржник, який прострочив виконання грошового зобов'язання, на вимогу кредитора зобов'язаний сплатити суму боргу з урахуванням встановленого індексу інфляції за весь час прострочення, а також три проценти річних від простроченої суми, якщо інший розмір процентів не встановлений договором або законом. Зі змісту вказаної правової норми випливає, що нарахування відповідних процентів та інфляційних витрат входять до складу грошового зобов'язання і 6 особливою мірою відповідальності боржника за прострочення грошового зобов’язання [5]. Отже, проценти, передбачені ст. 625 ЦК України, не є штрафними санкціями [6].

Узагальнюючи судову практику у споpax, що випливають 3 кредитних правовідносин Верховний суд України дійшов висновку, що положення ч. 2 ст. 625 ЦК України можуть застосовуватися незалежно від застосування кредитором інших видів відповідальності або інших забезпечувальних заходів, зокрема неустойки [7]. Беручи до уваги подібність правової природи пені та трьох процентів річних, передбачена цими статтями відповідальність може застосовуватись незалежно одна від одної. Чинне цивільне законодавство не забороняє визначення сторонами в договорі різних видів забезпечення зобов'язань. При цьому нарахування та стягнення неустойки (пені), в разі прострочення виконання зобов'язання, є правом кредитора, реалізація якого жодним чином не залежить від застосування інших видів цивільно-правової відповідальності, передбачених законом за порушення зобов'язання [2, с. 22]. Із зазначеного випливає, що у разі порушення умов договору споживчого кредитування позичальник зобов'язаний повернути кредитору суму кредитних коштів, сплатити проценти за час їх фактичного користування, суму вста- новленої договором неустойки а також заходи відповідальності за порушення грошового зобов'язання, передбачені ст. 625 ЦК України.

Розглядаючи відповідальність фізичних осіб за невиконання умов кредитного договору також слід проаналізувати можливість одночасного нарахування двох видів неустойки - штрафу та пені. Зрозуміло, що останні $\epsilon$ не самостійними цивільноправовими санкціями, а видами одного засобу впливу на правопорушника - неустойки. Відповідно до ст. 61 Конституції України ніхто не може бути двічі притягнений до юридичної відповідальності одного виду за одне й те саме правопорушення. Такий самий принцип знайшов своє відображення і у ст. 4 Протоколу № 7 Конвенції про захист прав людини і основоположних свобод [8]. Розглядаючи дане питання Верховний суд України дійшов висновку, що виходячи 3 положень ст. 549 ЦК України пеня і штраф не є окремими та самостійними видами юридичної відповідальності, проте, з принципу свободи договору випливає можливість застосування різних санкцій в межах одного виду відповідальності [7]. Це означає, що одночасне стягнення пені та штрафу за порушення кредитного зобов'язання можливе, і судам необхідно чітко з'ясувати умови кредитного договору: за які саме порушення боржником зобов'язання банк нарахував пеню, а за які - штраф; за які періоди порушення здійснені такі нарахування - і обов'язково відобразити ці юридично важливі обставини у своєму судовому рішенні. 3 цього приводу слід зазначити, відповідно до ч. 2 ст. 21 Закону України «Про споживче кредитування» пеня за невиконання зобов'язання щодо повернення кредиту та процентів за ним не може перевищувати подвійної облікової ставки Національного банку України, що діяла у період, за який сплачується пеня, та не може бути більшою за 15 відсотків суми простроченого платежу [3]. Про цьому, сукупна сума неустойки (штраф, пеня), нарахована за порушення зобов'язань споживачем на підставі договору про споживчий кредит, не може перевищувати половини 


\section{Цивільне, підприємницьке, господарське та трудове право}

суми, одержаної споживачем за таким договором, і не може бути збільшена за домовленістю сторін.

Однією з розрізняльних ознак договору споживчого кредитування $є$ його цільовий характер. У свою чергу в банківській практиці виділяють кредитні договори, що укладаються без встановлення якоїсь конкретної мети (на поточні цілі) та із прямою вказівкою напрямку кредитування (автокредит, освітній кредит, тощо). У першому випадку кредитор не вимагає від споживача звіту про витрачання кредитних коштів, втім, як правило, встановлюється обмеження щодо суми позики, застосовується більш тривала та складна процедура оформлення кредитних правовідносин. У другому випадку позичальник зобов'язується надавати кредитору можливість здійснювати контроль за цільовим використанням коштів. У зв'язку з цим до таких правовідносин застосовуються положення ч. 3 ст. 1056 ЦК України. Відповідно до вказаної норми, у разі порушення позичальником встановленого кредитним договором обов'язку цільового використання кредиту, кредитодавець має право також відмовитися від подальшого кредитування позичальника за договором.

\section{Висновки}

На підставі викладеного можна зробити висновок, що інструменти захисту прав та інтересів учасників кредитних відносин мають досить неоднорідний характер, оскільки вони в різній мірі базуються на таких феноменах як нормативні засади (закони та підзаконні акти, перш за все - норми цивільного права), приватноправові каузи договорів; стандарти правозастосування (зокрема, правові позиції судової практики). Останнім часом для України набуває помітного значення необхідність враховувати акти права EC, що є актуальним не лише для законотворчості але й для правозастосування.

На споживача-позичальника покладаються різні міри цивільно-правової та кримінальної відповідальності за порушення у сфері отримання фінансових послуг. Остання виникає внаслідок надання кредитодавцю завідомо неправдивої інформації з метою одержання кредитів (ст. 222 КК України) та вчинення незаконних дій із заставленим майном (ст. 388 КК України). Цивільноправова відповідальність споживача - позичальника виникає внаслідок невиконання або неналежного виконання обов'язку 3 повернення суми отриманого кредиту, його частини, або процентів, що нараховуються на нього, а також у зв'язку з недотриманням умови про цільове використання наданих коштів. Притягнення споживача до цивільної відповідальності регулюється загальними положеннями Цивільного кодексу України, що визначають правові наслідки порушення зобов'язання, з урахуванням особливостей, встановлених спеціальною правовою нормою, а саме, статтею 21 Закону України «Про споживче кредитування». Так, за домовленістю сторін до споживача можуть бути застосовані такі заходи, як розірвання договору, одностороння відмова від зобов'язання, відшкодування збитків, сплата неустойки, втрата застави. Крім цього позичальник має сплатити три проценти річних, передбачених ч. 2 ст. 625 ЦК України, оскільки така міра відповідальності може застосовуватися незалежно від встановлення в договорі інших заходів впливу, зокрема неустойки. Також можливим є одночасне стягнення пені та штрафу за порушення кредитного зобов'язання, якщо такі міри відповідальності встановлені договором за різного роду порушення його умов.

\section{Аітература}

1. Цивільний кодекс України [Електронний ресурс]: Закон України від 16.01.2003, № 435-IV// Верховна Рада України : офіц. веб-портал. - Режим доступу: https:/zakon. rada.gov.ua/laws/show/435-15\#n2644 (дата звернення: 21.02.2016). - Заголовок з екрана.

2. Иоффе О. С. Советское гражданское право. Отдельные виды обязательств : курс лекций / О. С. Иоффе. - Л. : Изд-во Ленингр. ун-та, 1961. - Т. 2. - 531 с.

3. Проект Закону про споживче кредитування [Електронний ресурс] : законопроект України // Верховна Рада України : офіц. веб-портал. - Режим доступу: http://w1.cl. rada.gov.ua/pls/zweb2/webproc4_1?pf3 (дата 
звернення: 21.02.2016). - Заголовок з екрана.

4. Кримінальний кодекс України [Електронний ресурс]: Закон України від 05.04.2001, № 2341-III // Верховна Рада України : офіц. веб-портал. - Режим доступу: https://zakon.rada.gov.ua/laws/show/234114 (дата звернення: 21.02.2016). - Заголовок з екрана.

5. Постанова Верховного Суду України від 06 червня 2012 року у справі № 6-49 цс 12 [Електронний ресурс] // Верховний Суд України : інформ. центр. - Режим доступу: http://www.scourt.gov.ua/clients/vs.nsf/ (дата звернення: 21.02.2016). - Заголовок з екрана.

6. Постанова Верховного Суду України від 17 жовтня 2011 року у справі № 6-42 цс11 [Електронний ресурс] // Верховний Суд України : інформ. центр. - Режим доступу: http://www.scourt.gov.ua/clients/vs.nsf/ (дата звернення: 21.02.2016). - Заголовок 3 екрана.

7. Постанова Верховного Суду України від 31.10.2012 року у справі № 6-47 цс [Електронний ресурс] // Вищий спеціалізованний суд України з розгляду цивільних та кримінальних справ. - Режим доступу: http://sc.gov.ua/ua/spravi_csho_vinikajut_iz dogovirnih_pravovidnosin.html (дата звернення: 21.02.2016). - Заголовок з екрана.

\section{SUMMARY}

The article analyzes the state of civil legal protection of the rights of individuals - borrowers in credit relations at the current stage of development of national legislation. It is argued that the differentiation of the system of remedies is carried out according to the criterion of their "resource and organizational weakness" of debtors in the studied legal relationships. It is necessary to provide the individual - the consumer of financial services with certain additional means of protection, which will result in the actual equality of participants in crediting. The existence of increased liability of the debtor in comparison with the measures of encumbrance on their unscrupulous counterparties is established. It is proposed to bring national legislation to the best standards of European practice in this field.

Keywords: Loan, credit, protection of civil rights, measures of civil liability, consumers of financial services.

8. Протокол № 7 до Конвенції про захист прав людини і основоположних свобод [Електронний ресурс] : Протокол Ради Свропи від 22.11.1984 р. № 7 // Верховна Рада України : офіц. веб-портал. - Режим доступу: http://zakon3.rada.gov.ua/laws/show/994_804 (дата звернення: 21.02.2016). - Заголовок 3 екрана. 